\title{
4
}

\section{The Soviet Legacy and its Transformation in the Russian IT Field}

Unlike many other fields of contemporary Russian industry, the IT sector was not built on the relics of Soviet enterprises but on the significant scientific, human, and social resources of the new Russian entrepreneurs. Despite this relative independence of the IT field from the traditional Soviet economy, our respondents live and work in a society that is still influenced by the socialist past in several ways.

In this chapter, this influence is considered in terms of the 'Soviet legacy' and the transformation of this legacy in post-Soviet Russia is discussed. The beginning of the chapter reflects upon both the constraining and the enabling aspects of the Soviet heritage, and searches for the roots of Russian entrepreneurship in the Soviet era. The remaining parts of the chapter describe the transformation of informal practices ranging from the Soviet way of using connections to the barter exchanges of the transition era and the role of 'kickbacks' in the present-day Russian IT sector.

\section{Constraining and enabling aspects of the Soviet legacy}

At first glance, our respondents seemed to have little to do with the Soviet legacy. With only a few exceptions, they had clear identities as capitalist entrepreneurs, directors, and managers. Many had indeed started their businesses practically from scratch and built modern IT enterprises through persistence and hard work. Upon detailed inspection, however, the continuing presence of the Soviet heritage in the present could be detected in relation to social structures, individual actors, and their personal networks. ${ }^{1}$

This presence of the Soviet past has often been called the 'Soviet legacy', and it is still used in various contexts to explain post-Soviet 
Russian life, most often as a shorthand way of referring to mainly negative phenomena. ${ }^{2}$ Under closer scrutiny, this legacy turns out to be a complex phenomenon.

Alexei Yurchak's view on Soviet legacy in his study Everything Was Forever, Until It Was No More: The Last Soviet Generation (2006) helps both to make sense of this complex legacy and to solve the enigma of how the seemingly eternal Soviet system could actually fall apart so easily and quickly. According to Yurchak this was possible because the Soviet system - despite its undeniable flaws and atrocities - also contained spaces for creativity and positive experience. Following John Austin's language theory, he differentiates between the 'connotative' and 'performative' functions of the language used in the 'late socialism' of Brezhnev's years. While the connotative function describes reality (an enouncement can be true or false), its performative function achieves actions in the world through use of language (e.g. taking an oath).

According to Yurchak, in late socialism there was a 'performative shift' in language use from connotative to perfomative dimensions. In other words, people participating in May demonstrations, voting or giving speeches in Komsomol meetings did not pay attention to the connotative dimensions since at issue was not the truthfulness of their speech but rather a performing of a ritual. This kind of participation in the common rituals of 'hypernormalized' language use at public meetings enabled citizens to continue functioning within the Soviet system, to which, in actuality, they had attitudes varying from hostility and indifference to full support of communist ideals. In other words, the performative use of language in official contexts allowed them to create alternative spaces for action and interests and to develop their own cultural activities (including Western rock music) in and outside the Soviet system.

On a general level Yurchak's approach adds an enabling dimension to the depictions of the Soviet system and deconstructs the binary views consisting of, for example, true believers in communist ideals and pretenders, official and unofficial, or public and private. Seeing the Soviet Union through these binarities prevents us from understanding the complexity of daily life in late socialism, and, by extension, paradoxes such as the communist system as a platform for the emerging new Russian entrepreneurs.

In the following sections the Soviet legacy will be discussed in terms of structures, actors, and networks, keeping in mind both the constraining and enabling aspects of this legacy. 


\section{Soviet organizations as platforms for the emerging economy}

\section{Komsomol}

The constraining structural aspects of the Soviet system on the economy have already been addressed in the previous chapter. In line with Yurchak's general idea, however, the Soviet era could also be considered to have contributed to the emergence of the IT field in several important ways. These enabling structural aspects of the Soviet legacy include the high level of mathematic-technical education, mass education of engineers, and the strong tradition in computer-related sciences which provided highly trained employees for the emerging IT sector. In addition, Soviet era organizational structures, such as Komsomol and particularly the high-level research institutions and universities in St. Petersburg, formed important contexts for the emerging Russian entrepreneurship.

According to Yurchak, the new Russian entrepreneurs had come from backgrounds in industry, science, the black market and Komsomol. In his view, many new Russian entrepreneurs had already acquired skills, knowledge, and competence under the structures of the late socialist Soviet system where no official private entrepreneurship existed (Yurchak 2002, 2006: 296-8). ${ }^{3}$ He notes how the success of many of the richest Russian businessmen could be traced back to their highranking Komsomol positions and describes how the Youth Centers of Komsomol allowed the emerging businessmen an aegis under which to put up the starting capital, find contacts, and transform non-cash funds into cash:

In the late 1980s, when the reforms of perestroika reached the sphere of economics and the Komsomol was allowed to experiment with private business activity, the knowledge, skills, and forms of rationality that consituted the late socialist entrepreneurial governmentality proved to be of crucial importance in this experimentation. At that time many active Komsomol secretaries started thinking of themselves as private entrepreneurs and businessmen, originally without necessarily giving up their identities as Komsomol secretaries. Eventually their work in 'youth centers' and 'cooperatives' under the auspices of the Komsomol organization turned many Komsomol committees into private firms and banks. 
Yurchak's account is lent credence by the descriptions of some of our respondents who told of having trained in entrepreneurial activities in the late 1980s and early 1990s at the 'Youth Center for Scientific and Technical Creativity' (Nauchno-Tekhnicheskoe Tvorchestvo Molodezhi, NTTM) functioning under the auspices of Komsomol:

At that time the business life started to develop. I organized on the basis of my dissertation topic a brigade which at the time was called temporary working brigade (vremennaia trudovaia brigada) (...) it was organized through NTTM. It was possible to work behind the back of the institute [where the respondent was officially employed] and arrange the payment through NTTM.

(technical director, p38)

Another of our respondents (director, p39) had similarly already organized his first, 'quite complex' commercial programming project at the end of the 1980s, through a Komsomol organization headed by his close relative. For the respondent it was evident that at that time this organization did not conduct youth-related activities anymore but closed different kinds of commercial deals.

\section{Universities and research institutes}

Because of the nature of the IT field and the concentration of several technical universities and research institutes in Leningrad, for many of our respondents their scientific and academic backgrounds and organizations were more important than their Komsomol connections.

Many respondents also noted their inclination toward and success in mathematics and/or computer science in school. All but two had graduated from university, and several had a licentiate or doctorate degree in computing-related sciences. For many, post-graduate studies in university or a job at a scientific research institute facilitated the acquisition of the human and social capital needed to start a private business.

Company director Egor (p42), for example, started his programming career in a British-Russian joint venture established at a scientific research institute in the early 1990s. Similarly, a well-known St. Petersburg software development company was founded in the early 1990s by young graduates from the university who wanted to earn a living with their skills in software design. In less than 20 years the firm has grown into an important player in the St. Petersburg IT field.

Another director (p22), with a background in the academic world, describes in a vivid manner his scientific activities at the research 
institute where he was writing his dissertation, and his gradual orienting toward entrepreneurship:

We made some new discoveries at the institute and everything was very interesting and fun. We sat there all night, worked around the clock. But then the excitement started to wear off. There were no more new discoveries. We ran out of adrenaline and started thinking how to live further. At the same time the first personal computers appeared and we started to do programming. (...) I already had a family and kids whom I should provide for somehow. (...) How could a graduate from matmekh [mathematical-technical faculty] make a living, one who has studied mathematics, programming and other subjects related to exact sciences? (...) Automatically one starts thinking of information technology.

(director, p22)

Though at face value this account resembles the starting phases of US firms established by study mates from major universities, the analogy is only superficial. For a US graduate careers in both the academy or in business were normal and customary options - though in both one had to face fierce competition. This was not the case in the Russia of the 1990s where academic careers seemed to have no future: one could not get by, let alone raise a family, based on the meager salaries in the academy. For one wishing to start a business, there were no models, business schools, institutions, or markets. One had to sink or swim.

A well-known example of the symbiosis between academic and business life in Russia is Lanit-Terkom, ${ }^{4}$ one of the biggest software firms in St. Petersburg, which was established and is functioning in close connection with the St. Petersburg state university. Averin and Dudarev (2003: 55) describe the nature of this symbiosis:

The company grew out of the System Programming Department (Mathematics and Mechanics Faculty) of the St. Petersburg State University, headed by the chief of department, Professor Andrey Terekhov. The utilization of the resources of the Mathematics and Mechanical Department gave the company an opportunity to use the knowledge and scientific background accumulated in the department during the decades of the Faculty's history. Moreover, the company has acquired a virtual monopoly over the highly qualified and talented staff - the teaching and research staff, as 
well as the best graduates of the department. At the moment, there is no clear boundary between the educational organization and the private company. Almost all teaching staff of the System Programming Department work for the company. The most talented students of the department are engaged in the company's projects within the framework of practical research (included in the curriculum) starting from 2nd-3rd years of education. Such a symbiosis is gainful both for the company and the department. The latter receives financial support and the opportunity to place its students in a job. Lanit Tercom is able, in turn, to prepare qualified personnel and to use the renowned name of the department in its marketing policy.

This is just one example of the survival strategies based on a symbiosis between the academic and business worlds in the early years of Russian transformation. However, as will become evident in Chapter 6 , in addition to academic or Komsomol background rooted in the Soviet era structures, a wide variety of other development paths for new software companies came to light in our data. One of them was illustrated by the 37-year-old CEO of a software company employing 80 people:

There was a factory which had problems and invited me to consult them. I looked around and saw that they had both problems and money. We suggested that they would give up their old software and we would write them a new one. They agreed. We gathered a group of people and started a project. In the course of this project we understood that the project would grow bigger than our temporary group of people and we founded a company.

(general director, $\mathrm{p} 3$ )

\section{Entrepreneurship and Soviet legacy}

As for the actors, the term Soviet legacy is often evoked in connection with the continuing role of the 'Soviet mentality' in present-day Russia. The connotations of the Soviet legacy are mainly negative, such as lack of enterprise, sticking to old routines, strict hierarchies, and so forth.

Although in general the IT sector in post-Soviet Russia is thought to be the least affected by the Soviet legacy, one respondent remarked that the legacy indeed still had an impact on domestic markets because 
of the 'red directors' working with the Soviet mindset and methods of management in customer companies:

When placing an order or making a deal there comes the moment of decision: to buy or not. Who buys, how and what. And then you will run straight into all these red directors.

(general director, $\mathrm{p} 3$ )

According to another respondent, the question of the Soviet mentality was connected to generations and was only relevant to those educated in the Soviet era, whereas the new post-socialist generation had new values and new problems:

P4: Today there has grown a completely new generation which is already in business life. Currently I deal with people who are not solely working in IT firms. They have managers of my age, that is, around thirty. We all went to school in the Soviet era.

Q: Do you have different values or do you work differently?

P4: I don't know, it is difficult to talk about the others. I can only say that in my mind those around thirty-thirty-five still remember school well. Those who finished school in the beginning of the 1990s already have completely new values and they look at life in a completely different way. In my head, the Soviet legacy still remains.

(general director, $\mathrm{p} 4$ )

An example of the problems of transformation for the Soviet generation was learning how to behave in business. This knowledge consists of, for example, working routines and habits and is accumulated over time in organizations but is rarely put into writing (cf. Podolny and Baron 1997). These habitual ways of acting are thus usually not learned from books but typically by imitating or interacting with colleagues or a mentor, or simply by doing.

One of our respondents, who had worked for most of his career in the Soviet Union, emphasized - in addition to learning new habits - the unlearning of the Soviet routines and ways of acting when comparing himself with the 20-year-old CEO of a well-known software company:

Q: There are things which are difficult to learn from books, which you can only learn through your own experience or by observing the experience of your older colleagues. For example, how to think in a new, innovative way, how to relate to people, how to conduct business. Have you had these kinds of cases? 
P1: Continuously.

Q: Can you tell examples?

P1: You have to understand that I was born in 1951 [year of birth has been changed]. At that time you had not even been planned yet, probably not even your parents, but I was already crawling, and then grew up in the Soviet Union. My whole mentality is Soviet. Imagine how hard it was for me to change, how hard it was to transform whereas my colleagues, e.g. my colleague in the company NewComp [name of firm changed] is now around 30. Have you yet been to NewComp?

Q: No.

P1: Well, look. This guy is older than you, about thirty. He started his business right after having finished at the institute. For him this is completely different. Of course I keep an eye on him and my other competitors. They are my teachers. I watch how they conduct business, how they regard their colleagues, how they organize everything. And I try to apply this (...) For them it all came naturally, but I had to get rid of the birthmarks of socialism.

(general director, $\mathrm{p} 1$ )

The same respondent illustrated the moral tension between socialist and capitalist mindsets with the dilemma caused by the installation of a new computerized system in his company to monitor workers:

For me it was very difficult to start [in the company] a computerized access control system, which records the time of arriving and leaving the workplace. Now I know who came later, who has not worked 40 hours a week. It was incredible, how difficult the implementation was for me. I felt as if I was being torn into pieces. What would the people think?

(general director, $\mathrm{p} 1$ )

Various techniques of controlling and monitoring workers were certainly also used both in the Soviet Union and other industrialized countries. The quote above thus rather illustrates the difficulties in the transition from the position of 'scientific rank-and-file worker' to that of a capitalist company owner and CEO, and the problems and tensions in balancing between the moral requirements of two conflicting sociopolitical orders.

There is, however, also another way of looking at the Soviet mentality. The studies of daily life survival strategies (e.g. Lonkila 1997), 
networks (Ledeneva 1998), and the abovementioned research by Yurchak (2002, 2006) suggest that the allegedly passive homo sovieticus could in the interstices of the system find spaces and possibilities for complex and innovative maneuvers. In fact, navigating in the opportunity structures of the late socialist and perestroika era allows us 'to speak about entrepreneurship in a context in which there was no market based private business per se' (Yurchak 2002; see also Shmulyar Gréen 2009).

In a similar vein Alf Rehn and Saara Taalas (2004) claim that the students of entrepreneurship have a lesson to learn about Soviet society, where, due to an ideological bias in research, entrepreneurship was not considered to exist at all. The authors even go as far as to claim that 'The Union of Soviet Socialist Republics might be seen as the most entrepreneurial society ever' and maintain that the Soviet system basically forced all citizens to become 'micro-entrepreneurs' in everyday life. They detect entrepreneurship and risk taking in unexpected settings also outside the business and market contexts and consider the blat networks to have been the main arena for entrepreneurial activity in the Soviet Union (Rehn and Taalas 2004). ${ }^{5}$ Blat networks in the Soviet Union and their transformation in post-Soviet Russia will be the focus of the next two sections.

\section{Blat: Transformation of the Soviet-era networking practice}

Blat denotes the Soviet habit of using personal relations to direct public resources to private uses. ${ }^{6}$ There are no exact English translations, but expressions such as 'using connections', 'pulling strings', and so forth give a rough understanding of the contents of the term. In this section the blat system and its transformation in post-Soviet Russia are described both according to Ilja Srubar's comparative investigation as well as Alena Ledeneva's studies of blat $(1998,2008,2009)$.

In his article on the actual nature of the socialist system, War der reale Sozialismus moderne? (Was the Real Socialism Modern?), Ilja Srubar (1991) presents an accurate theoretical description of the role of social networks in a socialist system. Though Srubar's analysis is based on comparison of studies of countries which made up the former Soviet bloc (not including the Soviet Union itself), the comparative aspect of the study strengthens the power of his argument. Srubar manages to show a similar kind of relationship between the socialist system and social networks in historically and culturally varied national contexts.

According to Srubar, the power monopoly of the Communist Party combined with the socialist shortage economy created a mechanism 
of social integration which was based on social networks and was specific to real socialist countries. In the shortage economy in addition to money the citizens also needed information about how and where to find goods in short supply. These goods and information were obtained through networks which developed into an alternative distribution system. Within the networks, an atmosphere of mutual solidarity emerged out of the reciprocal exchange relations, but it was limited to those who had something to barter, such as access to socialist property. These networks functioned parallel to the official system and were tolerated by the party since they compensated for the flaws of the shortage economy by diverting people's interests from politics to consumption. In addition, they functioned as a means of control since the party's tolerance for them could always be withdrawn.

While the shortage economy forced citizens to turn to their personal relations in order to get by, the party power monopoly produced a non-transparent state bureaucracy, the decisions of which could not be predicted by citizens. A position in this bureaucracy represented capital which could be traded through personal networks. This mechanism of social integration had a profound influence on the individual's social identity. Citizens in real socialism divided the world into the trustworthy 'us' - that is, one's personal network - and potentially hostile 'others.' Instead of general social solidarity, this integration mechanism produced fragmented solidarity within 'an archipelago of networks' and a worldview where moral norms applied to one's own circle were different from those applied to outsiders, for whom there was no moral way to success. A neighbor's wealth, for example, was attributed either to his political privileges or illegal activities in redistribution networks (Srubar 1991).

Parallel to Srubar, but independently of his research, Alena Ledeneva (1998, 2008, 2009, see also Lomnitz 1988) has studied blat in detail in the Soviet Union. Ledeneva bases her work on extensive field research and interviews filled with rich descriptions of the content, functioning, and practices of the blat ties.

Importantly for the themes of this book, Ledeneva defines blat precisely with the help of the notion of personal networks, as the use of personal networks for obtaining goods and services in short supply and for circumventing formal procedures. Blat networks channeled an alternative currency - an informal exchange of favors - that introduced elements of the market into the planned economy and loosened up the rigid constraints of the political regime' (Ledeneva 2009, 257-8).

However, though blat practices were conducted through personal networks, they were not identical, since the latter also had other functions, 
such as sociability. These functions were difficult to separate because 'blat merged with patterns of sociability to such an extent that people were unable to distinguish between friendship and the use of friendship. The boundaries became particularly blurred as the exchanged favors were favors of a particular kind - "favors of access"' (Ledeneva 2009: 258).

Blat had an ambivalent character since on the one hand it was necessary for the functioning of the system, but on the other hand it undermined the system and corrupted common morals through its very existence. Though blat practices made use of state resources, the state was dependent on the informal ways of distributing the scarce resources. The informal ways could not be discussed publicly, which created a double morality in Soviet society:

Thus blat became an open secret of Soviet socialism, well known but banned from political or academic discourse. The blat system of exchange was founded in the possibility of extending favors at the expense of state property. The dubious nature of state property and the repressive nature of the Soviet state contributed to pervasive practices of cheating and outwitting the state: blat and other forms of diverting state property, smuggling out (vynos), false reporting (pripiski), stealing, or absenteeism. These practices indicate not only the popular view of the Soviet state as parasitic, due to its highly exploitative nature, but also the mutual tolerance between the state and the citizens, especially in the Brezhnev era.

(Ledeneva 2008: 123-4)

Ledeneva shows how the inability of the Soviet economy to produce enough goods and services of decent quality, such as food products, medicine, cars, apartments, and so forth, led to resorting to obtaining them 'by blat' (po blatu). The examples of blat practices abound: an acquaintance working at a warehouse could arrange access to goods in short supply 'under the counter', a contact in the army ranks could arrange for avoiding the two to three years of military service, a doctor acquaintance in the hospital could arrange jumping the queue for better treatment or an operation, and so on.

Blat contacts penetrated the whole Soviet society: their amount was large and scale wide, but the common denominator was the use of social ties in order to gain access to state property or services and to use them for the private purposes of one's own circle. Ledeneva (1998: 39-58) distinguished blat from its 'extended family', including bribery, 
corruption, second economy, and patronage. For example, the difference between blat and bribery or corruption was that the latter were based on straightforward deals involving buying services with money. Characteristic of the blat services, on the other hand, were the long-term cultivation of relationships, a special vocabulary, and a refined etiquette of behavior where the straightforward offering of money could be considered insulting. This meant, among other things, that blat practices could penetrate areas where use of money could not.

Ledeneva also discusses the differences between blat and the various notions of 'informal' (unofficial, second, hidden, parallel, shadow, etc.) economy. She concludes that blat cannot be adequately analyzed in terms of informal economic practices since it implies relations of reciprocity within personal networks, rather than market-type exchanges and activities oriented toward profit, on which informal economic practices are often based. In her mind, the study of blat requires a sociocultural analysis of personal ties and their impact on blat exchanges.

Blat exchanges were based on reciprocal obligations. Ledeneva employs an idea borrowed from Pierre Bourdieu, according to whom the partners in a gift exchange take part in a collective 'misrecognition game.' In this game, the exchange of gifts can be perceived as altruistic only because of the time gap between the original gift and the countergift (see Chapter 7 for a closer account of reciprocal obligations).

Though Ledeneva's observations are in many ways extremely relevant to this study, the differences between blat exchanges and the exchanges dealt with in this book should be made clear. First, despite the misrecognition game, the blat system had in general a negative reputation: no Soviet citizen could have publicly admitted to having engaged in it. Partly because of this nature, asking a blat favor was often psychologically difficult (Ledeneva 1998: 156). This was not the case for our respondents with everyday exchanges of small favors, advice, helping out and so forth, most of which did not include a morally doubtful aspect. Second, and related to the previous point, blat transactions were about granting favor of access to state services or property, which were redirected to private use, whereas the majority of the favors and services dealt with in this book do not have that character.

\section{Blat in post-Soviet Russia}

In her later work, Ledeneva (2008) notes three major changes in blat practices. The first change concerns the expansion of the money economy, which has diminished the need for blat in personal consumption. 
Second, the privatization of the economy has changed the nature of 'favors of access' granted by officials. Instead of exchanging favors of access to socialist property for access to another distribution system, in the 1990s these favors came to be about privatizing state resources and converting them into private capital through various licenses and permissions. These exchanges between the state and business sector often turned into outright corruption. Third, the scale of blat exchanges has started to predominantly serve business instead of personal consumption (Ledeneva 2008: 132-3).

However, Ledeneva admits that informal contacts still remained a priority where money was not accepted as a means of exchange (1998: $180)$, and notes that blat was still used in state education and employment (1998: 206). Anna-Maria Salmi (2006: 38-9) adds to this list health services and job searches, which still offer much space for blat-type activities.

Ledeneva's (2009) recent assessment of the role of blat in post-Soviet Russia in 2009 is in line with these results. With the progress of monetary relations, blat has lost its relevance in everyday consumption but is still significant in, for example, the labor market, health care, and education. In her national representative survey conducted by the Levada Center in 2007, she asked respondents to define blat by choosing as many prompts as necessary:

18 percent of respondents indicated that the term is out of use and five percent noted that the word blatnoi means criminal - that is, has returned to its original pre-revolutionary meaning. At least a quarter of respondents associated blat with an exchange of favors (22 percent) or best described by a proverb 'I scratch your back, you scratch mine' (ty-mne, ia-tebe) (15 percent). With regard to formal constraints, the responses were: 'circumvention of formal rules and procedures' (17 percent), 'problem solving' (12 percent), 'blat is the necessity in order to give a bribe' (six percent) or gain access to administrative resources (four percent). Tellingly, only seven percent of respondents found it difficult to answer this question and there were respondents who offered their own definitions (including 'blat is higher than under Stalin' and 'blat is a leftover of socialism' (izderzhki sotsializma) as well as 'blat is the corrupt system, the whole industry' and 'blat is life'.

(Ledeneva 2009: 262)

Whatever the exact definition, blat still seems to have a central place in post-Soviet society since 66 percent of Ledeneva's respondents 
considered it either widespread (28 percent) or rather widespread (38 percent) in their own city or region.

In the following text the post-Soviet blat is illustrated by our interviews. Due to the nature of our data and methods, these illustrations are not claimed to be generalizable. At the end of this chapter their relevance will be evaluated through comparison with other studies of the topic.

The description by a St. Petersburg IT manager of the vanishing of blat practices seems to lend support to Ledeneva's conclusions. According to the respondent, the pressure of efficiency in capitalist enterprise does not leave room for blat in present-day Russia:

P1: In socialism, a person working as a butcher can get a carcass of an animal. Another person drives a taxi. A third one is a doctor and can obtain medical services. The butcher cuts the best pieces off the carcass and sells them at a normal state regulated price to the taxi driver or doctor. (...) And the bones he brings to the shop and sells to us engineers (...) Now, if the butcher needs to go someplace by car, he phones the taxi driver who drives him from one place to another. And the doctor will take care of him.

Q: And how does this work today?

P1: Today you go to the shop and buy. Anything is for sale.

Q: So where is there blat today?

P1: I told you an example of Soviet blat. Today it works on the level of old relations. But I believe it will soon disappear. Slowly blat will disappear.

Q: For example, in IT, in outsourcing there is almost no blat?

P1: In practice not. IT functions as other sectors. I can for example, appoint my brother as a manager in my firm. And he will turn out to be a good for nothing, he can do nothing. What will my colleagues say? We are trying to make money, what will they say?

(general director, p1)

Parts of this quote were questioned by other respondents, however. Though IT companies working with foreign customers were generally considered blat free, they too had to deal with blat-type phenomena if also operating on domestic markets. Moreover, in certain cases blat-type arrangements may be used either as an alternative to or in combination with bribing.

The interpretation of the term blat seemed to be connected to the age of the respondents. While elderly respondents, such as the one describing the blat relations among the butcher, taxi driver and doctor, 
considered blat in line with Ledeneva's account, marketing manager Valentina (p15), who was under 30 years of age, regarded blat as a synonym for the informal use of social relations in general. According to development manager Viktor ( $\mathrm{p} 17,33$ years) 'blat is not so relevant for young people. Many of them do not know, cannot imagine what blat means.' The hesitation of still another of our respondents, a director under 30 years of age, lends support to this:

Blat - it is a tough word. If you define it formally ... how would you define it formally?

(director, p10)

Varied opinions were expressed about the existence, nature, and specificity of post-Soviet blat. A director-owner of his own company, aged 50 (CEO, p16) - who thus had his own experiences of Soviet blat - compared blat to 'protection.' A technical director under 30 (p11) saw blat as a Russian version of a universal way of acting that is not inherently immoral.

Despite these variations, a common view was that blat still exists in the public sector and big state-owned companies. In particular tenders organized by the state-related actors were considered to be impossible to win without blat, bribes, or both. The founder of a young and small company expressed this explicitly:

We [respondent's firm] probably have not yet reached the level where you participate in tenders, but I know that they are indeed won by those who have acquaintances. If, for example, the five leading firms of my field try as hard as they can, the tender will be won by those with connections anyway.

(technical director, p20)

Another respondent doing business with state structures refused to answer this question ('confidential'), but the third respondent, working in system integration, confirms the quote above:

In fact, in some market segments it [blat] definitely exists. This was particularly visible in system integration which is closely related to the state purchases. It is practically impossible to win a tender without corresponding connections, friends, acquaintances, kinfolk. But this is actually no secret. I am not revealing any secret.

(marketing manager, p18)

When asked about concrete examples of present-day blat, in addition to state structures, employment by blat was mentioned. Marketing 
director Svetlana (p6) also referred to the arranging of study places by blat - a phenomenon about which there are a lot of rumors and anecdotal evidence from both the Soviet Union and post-Soviet Russia:

Q: In the Soviet era blat relations were still used. Do they still function, does blat exist nowadays?

P4: In state structures it stays as it was. In my opinion there is no doubt about this. But in business - this is a complex question. It is clear that parents try to push their children forward through all means. This is a normal parental instinct, and here blat functions. Another matter is that it functions precisely as an exchange of favors. I have an example in mind, where a big boss arranged for his children to work in different companies. With this it happens often that the child does not correspond to the requirements presented by the companies. But the child was employed precisely because dad had given in one way or another a favor to this company. And so this happened in full scale. As for business, I think that in big companies this also functions, but not in small ones. Here I doubt it.

Q: Why?

P4: In small companies people are visible (na vidu), everything is counted and the budget is small. If a small company has to employ someone to win a state organized tender, this causes a financial calculation: How much do we lose by employing this kid and how much do we win by getting this order.

(general director, $\mathrm{p} 4$ )

In all, despite the significant changes compared to Soviet-era blat, the present-day Russian society and economy still seem to leave room for informal practices more or less reminiscent of blat. Even though these practices may be neither as pervasive nor culturally specific as in the Soviet Union, they still continue to exist, particularly in the public sector and state-controlled parts of the economy.

\section{Barter: A transitory phenomenon of exchange}

Where blat was mainly a phenomenon of the Soviet system, barter (non-monetary exchange between companies) peaked in the late 1990s (see Figure 4.1). ${ }^{7}$ Barter will be briefly described here as an example of informal socioeconomic practices of the transition era based on personal connections. According to Caroline Humphrey (2000a), postSoviet barter was a unique phenomenon on the global scale, since never 
before had an economy as big as Russia's operated to a large extent through barter.

Though barter exchanges took place in the Soviet Union as well, according to David Woodruff (1999), the 'barter of the bankrupt' of the transition era was a qualitatively different phenomenon with new causes and new consequences. In his mind the new barter was not only an anomaly threatening the implementation of the market reforms, but also a sign of how the reformers had neglected the central role of monetary consolidation in state building.

According to Ivanenko and Mikheyev (2002; see also Clarke 2000: 178-9), in the background of barter there were the structural weaknesses and bottlenecks of the socialist system. The Soviet economy had built a massive industrial production system which was connected to an inflexible and one-sided distribution, trade, and banking network. Big production plants, for example, were planned to serve certain customers and get raw material from certain producers. When one part of the logistic chain saw trouble, this was reflected in the whole chain:

For example, as steel producers in the Ural region found the demand for their products falling, they became unable to pay suppliers in cash and offered metal products for coal. The coal mines, being unable to find alternative customers along the existing transport lines, had to agree.

(Ivanenko and Mihkeyev 2002: 411)

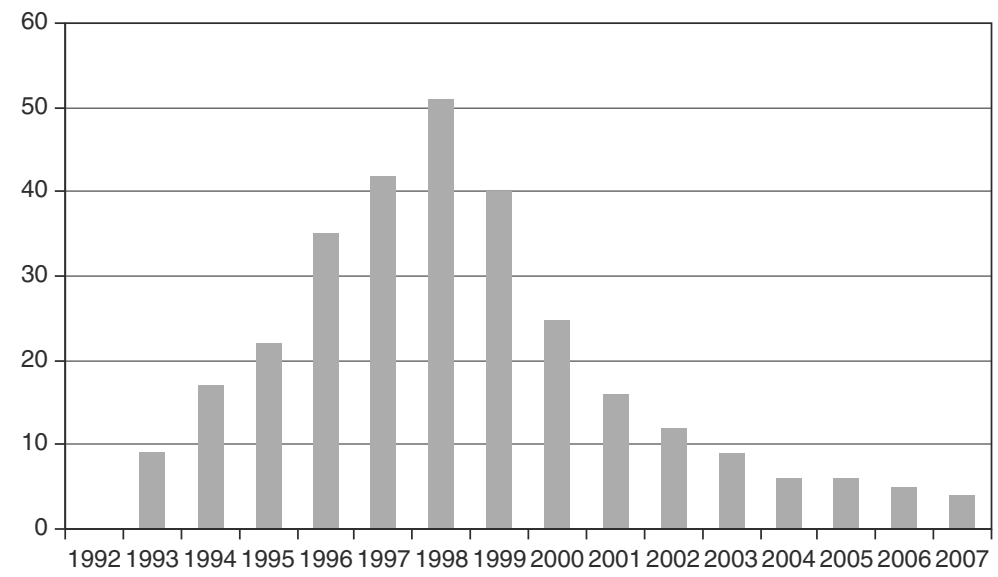

Figure 4.1 The share of barter in Russian industrial sales, 1992-2007, \% 
In addition to leading to barter between companies, the demonetization of the post-Soviet Russian economy in the 1990s also affected households, since some salaries were paid in non-monetary forms (see Clarke 2000: 189-94). Because the retail trade and provision of consumer services were, however, mainly monetary, individual households had to react to the new situations either by lowering their standard of living (Clarke 2000) or by selling the goods received at the workplace on streets and highways or in marketplaces.

It is not our intention to review the large research literature on barter here (see for example Seabright 2000a; Ivanenko and Mikheyev 2002; Woodruff 2000). It suffices to say that barter was not only an economic but also a social phenomenon operating through social relations (Seabright 2000b: 8). Consequently, the studies most relevant for this book are those analyzing the dynamics of barter on the micro level (Humphrey 2000a, b; Ledeneva 2000, 2006; Clarke 2000).

Though barter took place between companies and organizations, the practical deals were handled by individuals, and the barter arrangements and exchange chains were often built upon complex chains of exchanging parties (Ledeneva 2000: 298-317, 2006: 115-41). These arrangements were partly founded upon already existing networks, and partly they created new relationships balancing between trust and coercion (Humphrey 2000a, b). Most importantly, the majority of the barter deals were not conducted directly between the exchanging firms but through middlemen (Ledeneva 2006: 125).

In actual fact this means that the Russian economy in the 1990s formed an immense network consisting of the companies (and their workers who were paid in kind) and the middlemen mediating the exchanges. These networks, on the base of which Russia's current form of capitalism was partly built, relied on personal contacts:

[G]ood personal contacts are vital for making the offsets agreed upon between the parties, for designing schemes, and for making these schemes work. Negotiation skills may help to acquire weak links for the schemes - partners engaged on a rather short-term basis - but it is personal contacts that provide strong links in these schemes, those characterized by absolute trust or long-term technological partnership.

(Ledeneva 2006: 138-9)

In their criticism of the presuppositions of the transition debate, Michael Burawoy and Katherine Verdery (1999b) have stated that in spite of a 
linear transition from socialism to a market economy, development in Russia will most probably be an uneven development of different sectors of society with occasional 'backlashes'. Though barter will hardly reach the prevalence of the 1990s again, there have been some signs of the return of barter practices on a smaller scale after the beginning of the economic crisis in 2008. Belchenko (2008), for example, describes how certain companies in the Krasnoyarsk region in the beginning of December 2008 paid their workers' salaries in the company's products instead of money. ${ }^{8}$

\section{Otkat: The role of 'kickbacks' in the Russian economy}

While blat was mainly a Soviet era phenomenon, barter peaked at the end of the 1990s, after which it slowly disappeared. Instead of blat and barter, many of our respondents mentioned the rise of otkat, an expression for a post-Soviet form of corruption. It roughly corresponds to the English word 'kickback' and, as the Russian discussants are eager to note, is not a particularity of the Russian economy: the first 'AntiKickback Act' was passed in the US already in 1946 and was amended in 1960, 1986, and 1994 (Denisov 2005). ${ }^{9}$

Otkat is a noun from the verb otkatit' (roll away, roll back). In actual terms it means that a company participating in a public tender promises to 'roll back' a certain amount of the contract sum to the organizers of the tender. Otkat is therefore a form of corruption that is not specific only to Russia, and there is no reason to believe that foreign firms operating in Russia would not use otkat. What seems to be particular however - concluding from our interviews, the views of Russian observers (e.g. Denisov 2005; Gorbachev 2007) and other information about corrupted practices in Russia - is the prevalence of otkat in Russian business.

This prevalence is in line with the general information on corrupted practices in the Russian economy and society, and its actual practices are spiritedly debated both in Russian journals and on Internet forums. Giving otkat is often euphemized as 'personal bonus' or 'discount', and the negotiations concerning the deal may be conducted using language which at every point in time could be interpreted as referring either to a completely transparent and legal deal or a kickback agreement:

In the beginning of the discussion it is very good to test the waters with the potential recipient of otkat with the phrases with double meaning: 'For you it will be very profitable (vygodno) to deal with 
our company', 'we are ready to make concessions (poiti navstrechu) so that you would choose our company', 'a reduction may be arranged in any form convenient (udobno) for you'.

(Gorbachev 2007)

During such conversation the rich Russian language gives plenty of opportunities to interpret the word 'you' as 'you personally' instead of 'your company', and the well-reflected pauses of speech, change of intonation or tone give an impression of the hidden message behind what is meant to be a transparent deal between the representatives of the two parties, and give the opponent chances to express understanding of this message (Gorbachev 2007).

Though otkat is not a big problem in the IT companies operating mainly in foreign markets, many respondents mentioned it in discussions about the transformation of blat in post-Soviet Russia and Russian domestic markets:

Q: Sometimes in the Soviet era blat relations were used. Does this still function?

P9: It only turned into corruption. Of course it functions.

Q: Have you run into some examples?

P9: Not personally, because I work with foreign business and there this does not exist in general. But in Russia - of course. I don't think you will find a line of business which functions without otkat and all this.

(director, p9)

Otkat was taken up by several respondents in connection with tenders which, according to the respondents, were won either through relations or otkat, or both. According to another respondent (director, p29) who had worked with Russian companies on domestic markets for a long time, tenders are rarely won based on 'objective' criteria, but with connections and, lacking connections, by otkat. At the moment his firm did not participate in tender, considering it a waste of time and resources because the result was predestined:

The firm will do a huge amount of preparation, but the tender will be won by a crazy proposal only because of connections.

(director, p29)

Another respondent, a technical director working with big companies, told openly of the various forms of otkat, claiming that in practice all 
state officials (chinovniki) take bribes, and still another admitted that his firm had been involved in otkat.

Obtaining reliable information about the prevalence of otkat (or blat or barter) is understandably hampered by the several problems related to data and methods. One necessarily simplistic and limited way of approaching the subject is to examine the prevalence of these terms in the Russian media. Figure 4.2 is based on a scrutiny of selected Russian newspapers and magazines published in 1992-2007 and stored in the Integrum database. It shows how in the texts of central Russian newspapers and magazines the term otkat has become more common during the 2000s while the use of barter and blat has diminished (see Figure 4.2). ${ }^{10}$

Though the frequency of these terms in the media is not in direct correspondence with the occurrence of the phenomena in Russian society, it is noteworthy that the estimate of the peak of barter in Figure 4.1 is quite similar to the frequency of the term in printed media in Figure 4.2.

The pervasiveness of corruption in Russia has also been addressed by Russian presidents - up to now without results. The latest data by Transparency International's Corruption Perceptions Index ${ }^{11}$ indicate a fall in Russia's ranking from 121 in 2006 to 143 in 2007, and to 147 in 2008, while in 2008 the US was eighteenth, the UK sixteenth and Finland fifth (see Figure 4.3).

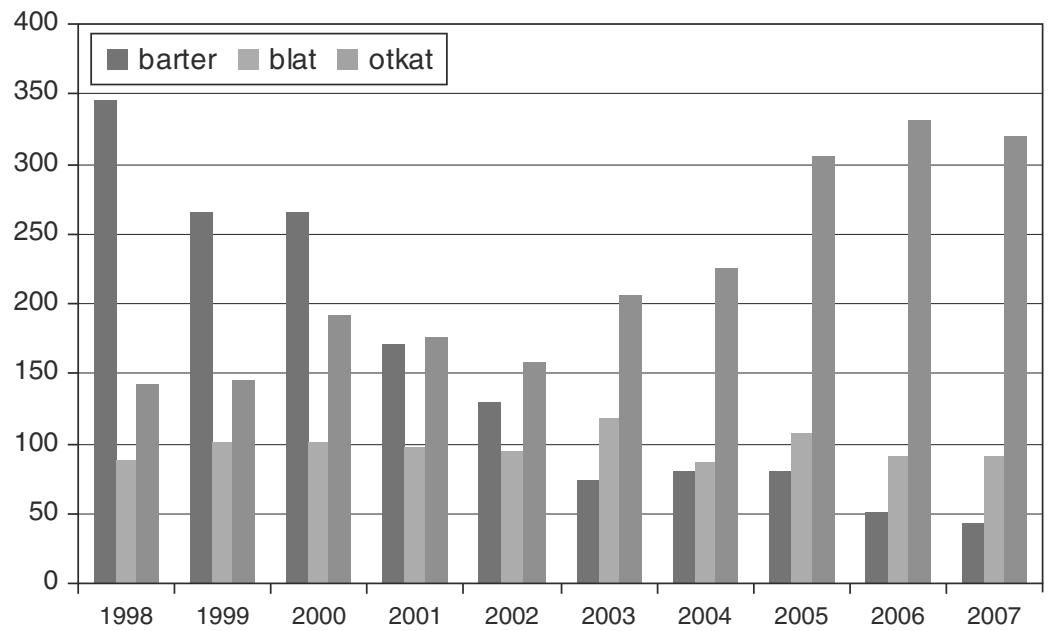

Figure 4.2 The frequency of use of the terms blat, barter and otkat in selected Russian newspapers 1998-2007 


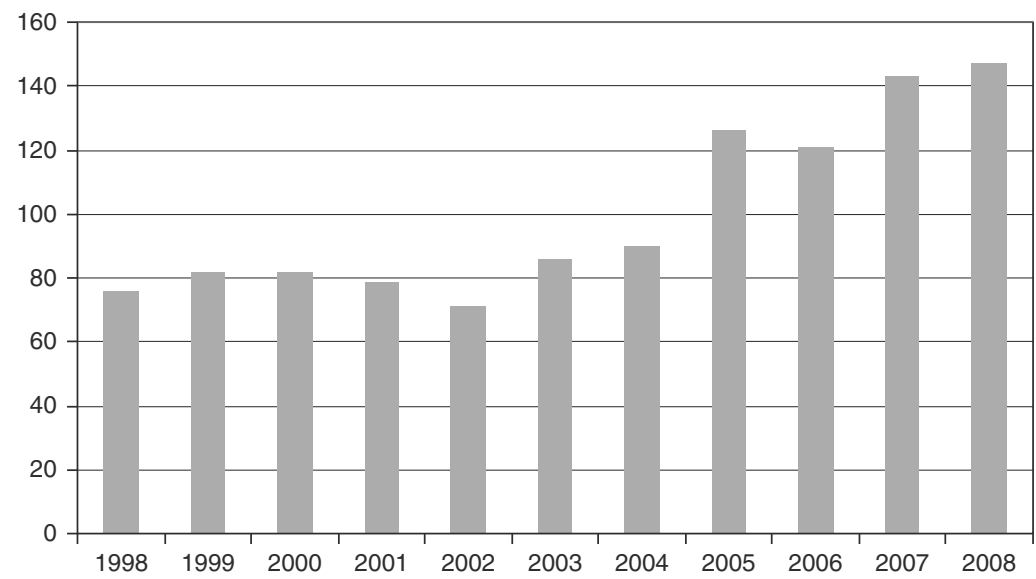

Figure 4.3 Ranking of Russia in Transparency International's Corruption Perception Index

Figure 4.3 shows the deterioration of Russia's ranking during the 2000s despite the anticorruption speeches and campaigns. Russia's closest neighbors in the index in 1997 were Pakistan and Columbia and in 2008 Indonesia and Togo.

The aim of this study is not the analysis of corruption in Russia. Therefore the processes and structures at the base of the corruption index rankings will not be investigated in detail (see, e.g. Lovell et al. 2001). However, even without a detailed analysis one may draw the conclusion that Yeltsin, Putin, and Medvedev have not succeeded in weeding out wide-scale corruption, which seems to be a systemic characteristic of the society and economy, from Russia.

The referrals to corruption and illegal or ambiguous practices in the interviews were mostly related to dealing with state structures. Understandably, most respondents did not clarify these things to the interviewer either because of unwillingness or because they were not responsible for communicating with these structures within their companies. The following interview quote shows how a question not originally meant to refer only to state structures was interpreted as such by the respondent and how the native Russian interviewer read between the lines of the respondent's reply:

Q: Have you sometime been in situations in business, where you could not solve the problem in a formal way and you had to lean on some informal relations, contacts? 
P20: Again here it is a question related to state structures. I do not know how this all goes, I do not deal with these things.

Q: Do you mean bribes? OK, it is not a secret to anyone, what there ... Is this related to accounting?

P20: No, not to accounting. I will not answer this question.

(technical director, p20)

One of the few respondents who overtly told of illegal practices such as tax evasion was working in a small company employing only a few people and in a field representing a small fraction of the ICT sector. ${ }^{12}$ In his field one did not, in the early 2000s, work on written contracts but on the basis of 'gentlemen's agreements', because 'practically all money goes over the taxman's head'. According to the respondent probably one ruble out of 20 was reported to the taxman in falsified official contracts, the monitoring of which was based on social control and the reputations of actors within the small and specialized markets. Another respondent lent support to this view, stressing the similarity of the business environment for all Russian companies:

[I]n general, companies work in a similar manner, which is defined by the legal environment. The legislation of the Russian federation contains directly both the juridical and financial aspects: taxes, banks and so forth. And I know that up to this day all firms work by and large according to the same model. There are very few firms that pay full taxes.

(general director, $\mathrm{p} 4$ )

According to still another respondent (general director, p48) working in telecommunications it is not a secret that most of the telecommunications technology sold in St. Petersburg is 'gray', that is, not imported according to legal customs regulations.

Because of the particular nature of the software design sector (relatively small turnover, large share of human and educational capital, orientation abroad), extortion and other forms of organized crime did not emerge as important issues in the interviews. A programming company is less vulnerable to extortion or takeover by criminal groups than, say, a distribution chain of food products. However, particularly in the 1990s, keeping a low profile was considered to be a precaution against these practices, and probably also against the taxman:

Until 1999 our company was not visible anywhere (...) But the level of criminality was at that time much higher than today - thank 
God. And we did not want to be seen, to be known of or heard of here.

(general director, $\mathrm{p} 1$ )

Things were different in the hardware business. Technical director Kirill (p38) remembered a meeting among Russian ICT companies at the beginning of the 2000s. A merry group of software designers was approached by an entrepreneur in the hardware business, who smiling sadly told the entrepreneurs 'How well things are with you, nobody beats up or kills anyone'. ( $N u$, kak $u$ vas khorosho, nikto nikogo ne izbivaet, nikto nikogo ne ubivaet.)

\section{Other informal practices in the post-Soviet Russian economy}

In her book How Russia Really Works. The Informal Practices That Shaped Post-Soviet Politics and Business (2006) Alena Ledeneva extends her studies of blat to other forms of informal practices in post-Soviet Russia which have gained ground parallel to blat losing its central role. She defines informal practices 'as people's regular strategies to manipulate or exploit formal rules by enforcing informal norms and personal obligation in formal contexts. Such strategies involve bending both formal rules and informal norms, or navigating between these constraints, by following some and breaking others' (Ledeneva 2008: 119, 2006).

The informal practices include, in addition to the barter dealt with earlier in this book, the use of 'black PR' and kompromat (gathering and fabricating blackmail files for political or business purposes), the principle of krugovaia poruka (joint responsibility and mutual obligations of a closed social circle), double accountancy, financial scheming, and alternative law enforcement. As with blat, the nature of these practices is considered ambivalent, both reproducing and undermining the postSoviet society and economy:

I argue that informal practices were an integral part of the postsocialist transformation. Informal practices adjusted to and were shaped by formal and informal constraints: they supported formal rules and informal norms but also subverted them; they rapidly accommodated legal changes but also created an obstacle to further change; they were beneficial for certain individuals but also made them hostages of the system. These practices were not simply illegal but integrated the law into political, media, and business 
technologies, often manipulatively. Similarly, they did not simply follow or contradict informal norms but relied on some of them and played one set of norms against the other.

(Ledeneva 2006: 190)

Ledeneva's illuminative case studies describe, among other things, different types of sanctions as part of the informal practices:

The first area encompasses a set of administrative sanctions, that can be organized through well-placed links to official structures such as regional administrations, the tax inspectorate, tax police, the fire department, and the departments of sanitation and public health. It is possible to arrange for a firm's access to water, gas, electricity, and sewers to be cut off by the regional authorities on the pretext of arrears. These techniques have been practiced widely and remain one of the most common ways of neutralizing opponents.

(Ledeneva 2006: 172-3)

Another example of informal practices presented by Ledeneva is the possibility of influencing official investigations and judicial proceedings in Russia. Law cases and investigations can be opened or closed by influencing judges, prosecutors, or police, and if unfavorable judgments are passed, their enforcement can be prevented (Ledeneva 2006: 174).

Informal practices are conducted both in politics and business - and at the intersection of the two spheres. Ledeneva cites a case published in Kommersant in 2001 where as part of an anti-black PR action a St. Petersburg agency offered money for 21 press outlets to publish commercial disinformation (a nonexistent company opening a nonexistent shop at a nonexistent address) as an editorial form rather than as a paid advertisement. As a result, 13 outlets agreed to publish this information as an article for prepayment, three recommended to publish it as advertising, four wanted additional information and one published it for free (Ledeneva 2006: 35, citing Kadik and Pyanykh 2001).

Ledeneva's examples of kompromat contain, among others, cases of Russian businessmen's and politicians' suspicious political activities (abuse of office and power); shady and often illegal economic activities (e.g. misuse of budget funds, capital flight, giving or accepting of bribes); criminal activities (contract killings), and compromising details of private life (spending habits, sexual orientation) (Ledeneva 2006: 58-90). 
Krugovaia poruka refers to 'a pattern in behavior or relationship according to which a person is part of a bigger social unit (a group, network, family, or clan) rather than an isolated human being driven by self-interest. Such a social unit is "tied up" by joint responsibility and mutual obligations' (Ledeneva 2006: 90). The genealogy of krugovaia poruka has long roots in both prerevolutionary Russian and Soviet history and its forms have been continuously changing and adapting to the new circumstances. In post-Soviet Russia the principle of krugovaia poruka can be found both in politics and business, often connecting the two spheres as with the 'Mabetex case' against Pavel Borodin, the Kremlin property chief, whose bailing out of Swiss prison was considered to be due to his inside knowledge of Kremlin affairs reaching up to Yeltsin and his inner circle (Ledeneva 2006: 107).

Similar to blat, krugovaia poruka overlaps with the use of personal networks, but is not identical to it. It underlines that in Russian political culture:

-The individual is viewed as a part of a bigger system (such as a circle of svoi liudi [one's own people] or a network of interests) rather than isolated and working for oneself

- Individuals are encouraged to seek protection and to repay favors.

- Long-term relationships are kept and nurtured, thus creating mutual dependency rather than operating on the basis of short-term individual gain.

- Governance is by flexible ethical standards rather than by the strict rule of law.

(Ledeneva 2006: 113)

Ledeneva also offers a detailed account of a variety of financial scheming related to double invoicing, capital flight, tax evasion, or tax avoidance which the participants see as necessary survival strategies for protecting themselves against turbulent and changing institutional environments, corrupted authorities, and the arbitrariness of the tax inspection. On the systemic level the financial schemes, however, create a vicious cycle, undermining formal institutions and decreasing their effectiveness (Ledeneva 2006: 161).

\section{Prevalence of criminal practices in the Russian economy}

Does the long list of informal practices referred to in this chapter imply that the Russian economy is completely dominated by illegal 
practices or run by dubious, half-criminal groups? Due to its qualitative nature, this study cannot answer the question of the prevalence of illegal and informal practices in the Russian economy. However, the interviews suggest that most prone to corruption, otkat and other informal practices are the IT firms dealing with the hardware trade and those doing business with state-owned or state-controlled sectors.

These conclusions are supported by Chachin (2008), who cites a report by the Commission of Telecommunications and Information Technology of the Russian Union of Industrialists and Entrepreneurs. According to the Commission, the state has not been able to monitor the observation of customs and tax regulations. Therefore the majority of Russian IT imports are effectuated by 'gray schemes':

[A]voiding value-added taxes and customs (...) leads to the offering of 'gray' IT products to markets 30-35 percent cheaper than is possible for entrepreneurs who pay full taxes and customs. As a consequence all Russian and foreign firms working in Russia are forced to play by the rules, with which many disagree, but which they have to follow.

(Chachin 2008)

Moreover, the commission notes how the equal level of social security payments in all fields of industry particularly hampers the competitiveness of the labor-intensive IT sector, forcing Russian IT firms to use 'gray' schemes of payment. This distorts the accounting and makes Russian firms 'untransparent' to foreign investors.

The role of illegal and criminal aspects of the Russian economy have been also analyzed by Vadim Volkov (2002) who has proposed an interpretation stressing the civilizing effect of capitalism on organized crime in post-Soviet Russia. Volkov does not deal with organized crime as a deviant phenomenon, but sees it instead from a neoinstitutionalist perspective as a response to the requirements of the emerging Russian markets. For him, organized Russian crime was not a rampage of bloodthirsty killers, but the organization and commodification of violence by the 'violent entrepreneurs' - often called 'Russian mafia' by other writers.

According to Volkov's theory, the Russian state in the 1990s was fragmented and weak. It had lost both the fiscal monopoly and the monopoly of force, and could not secure the property rights or other needs of the emerging Russian economy. The splitting of the KGB into 
five separate agencies by Yeltsin's government in order to diminish the power of Soviet structures led unintentionally to the birth of protection markets in Russia. A great number of unemployed state security officers from the power structures (silovye struktury, e.g. security services, interior, and defense ministry) moved to the newly established private security agencies.

These 'violence-managing agencies' such as criminal groups, private protection companies, and police and security forces acting as private entrepreneurs took over many of the functions of the unstable Russian state and, therefore, were an inherent part of post-Soviet Russian statebuilding. For a beginner businessman, they were a more effective option for settling disputes than turning to the state.

The tightening of competition in the protection business created new informal rules in the turmoil. Some criminal groups were pushed out of the markets, but many were integrated into the local economies and politics. Former criminal leaders became managing directors, who employed public relations consultants to polish their public image. Stabilization of the environment made resorting to violence unprofitable and offered the Russian state a chance to regain the monopoly of force that it had lost under Yeltsin's rule. Ultimately, the violent entrepreneurs paved the way for Putin's government and the strengthening of the Russian state in the 2000s.

In short, according to Volkov, organized crime did not capture the Russian state but participated - without being conscious of it - in the creation of an order within chaos. Thereby the violent entrepreneurs were actors in the state-building process of post-Soviet Russia, during which they were transformed from thugs into economic actors.

All in all, while Volkov's (2002) work stresses the civilizing effect of the markets, Ledeneva (2006) paints a darker picture of contemporary Russian business life. According to her, 'every legal firm or structure is forced (in order to preserve itself) to engage in underground financial scheming, usually having to do with its ownership structure, concealed profits, and multiple accounting systems' (Ledeneva 2006: 160).

A mediating view between Volkov and Ledeneva, though closer to the latter, was offered by a St. Petersburg businessman from whom I asked at the end of 2006 if it is possible to conduct business strictly according to the laws and other official regulations. The reply was 'it is complex, but possible' (slozhno, no mozhno).

Both Ledeneva's (2006) and Volkov's (2002) studies deal mainly with the 1990s, and the development during the Putin-Medvedev era requires 
new empirical research. For the purposes of this book it is important to note that neither blat, nor barter, nor corruption debates are the whole truth about the role of social networks in the Soviet Union or today's Russia. The various ways of networking find themselves rather on a continuum ranging from illegal or immoral to completely legal and moral ways of action. It is the latter that the remaining chapters of this book will discuss. 